\title{
https://doi.org/10.1038/s42003-020-01237-0 OPEN
}

\section{Publisher Correction: Transcriptomic and proteomic signatures of stemness and differentiation in the colon crypt}

Amber N. Habowski[D, Jessica L. Flesher (1), Jennifer M. Bates, Chia-Feng Tsai@, Kendall Martin, Rui Zhao, Anand K. Ganesan, Robert A. Edwards (B), Tujin Shi B, H. Steven Wiley, Yongsheng Shi, Klemens J. Hertel \& Marian L. Waterman (D)

Correction to: Communications Biology https://doi.org/10.1038/s42003-020-01181-z, published online 19 August 2020.

In the original version of the published Article, the URL given in reference 77 for the associated protocol on the Protocol Exchange was incorrect. The error has been corrected in the HTML and PDF versions of the Article.

Published online: 03 September 2020

\footnotetext{
(c) (i) Open Access This article is licensed under a Creative Commons Attribution 4.0 International License, which permits use, sharing, adaptation, distribution and reproduction in any medium or format, as long as you give appropriate credit to the original author(s) and the source, provide a link to the Creative Commons license, and indicate if changes were made. The images or other third party material in this article are included in the article's Creative Commons license, unless indicated otherwise in a credit line to the material. If material is not included in the article's Creative Commons license and your intended use is not permitted by statutory regulation or exceeds the permitted use, you will need to obtain permission directly from the copyright holder. To view a copy of this license, visit http://creativecommons.org/licenses/by/4.0/.
}

(C) The Author(s) 2020 